\title{
THE EFFECT OF AWARENESS, MORALITY, TAX CULTURE, AND DISTRIBUTIVE JUSTICE ON THE TAXPAYER COMPLIANCE
}

\author{
Ina Nurlela, Asep Kurniawan, Indah Umiyati
}

Sekolah Tinggi Ilmu Ekonomi Sutaatmadja, Indonesia

Email: inanurlelamail@gmail.com

Email: asep.stiesa@gmail.com

Email: indahumiyati@gmail.com

\begin{tabular}{l}
\hline INFO ARTIKEL \\
\hline Histori Artikel : \\
Tgl. Masuk : 1 Januari 2021 \\
Tgl. Diterima : 15 Februari 2021 \\
Tersedia Online : 31 Maret 2021 \\
\hline Keywords: \\
Awareness; Distributive Justice; Morality; \\
Taxpayer Compliance; Tax Culture; SME
\end{tabular}

\section{PENDAHULUAN}

Indonesia merupakan salah satu negara dimana pendapatan utama dari sektor perpajakan, dimana ini nantinya akan digunakan untuk perkembangan dan pembangunan negara itu sendiri termasuk untuk kesejahteran masyarakat. Selain itu juga, Pajak merupakan salah satu sumber pendapatan negara terbesar yang digunakan untuk membiayai kegiatan pemerintah, memajukan kesejahteraan umum serta mencerdaskan kehidupan bangsa sebagaimana yang tertuang dalam Undang-Undang Dasar 1945 alinea ke-4.

Hal ini tertuang dalam Anggaran Penerimaan dan Belanja Negara (APBN) dimana penerimaan pajak merupakan penerimaan dalam negeri yang terbesar. Semakin besarnya pengeluaran pemerintah dalam rangka pembiayaan negara menuntut peningkatan penerimaan negara yang salah satunya berasal dari penerimaan pajak. Direktorat Jenderal (Ditjen) Pajak sebagai instansi pemerintahan di bawah Departemen Keuangan sebagai pengelola sistem perpajakan di Indonesia berusaha meningkatkan penerimaan pajak dengan mereformasi pelaksanaan sistem perpajakan yang lebih modern (Adiasa, 2013).

Pendapatan negara dari sektor pajak mengalami peningkatan setiap tahunnya dan pada tahun 2018 lalu menjadi pencapaian yang tertinggi dibandingkan dengan realisasi pada tahun-tahun sebelumnya. Namun, hanya pada tahun 2014 realisasi peneriamaan pajak melebihi target. Sedangkan dari tahun 2015-2018 sampai saat ini penerimaan belum memenuhi target yang diharapkan. Hal ini dapat dilihat dalam tabel sebagai berikut: 
Tabel 1.1

Realisasi Penerimaan Pajak

\begin{tabular}{|c|c|c|}
\hline Tahun & Target & Realisasi \\
\hline 2014 & Rp. 579.637.413.238 & Rp. 650.637.413.238 \\
\hline 2015 & Rp. 999.095.326.999 & Rp. 852.393.786.400 \\
\hline 2016 & Rp. 1.222.042.739.000 & Rp. 761.629.132.254 \\
\hline 2017 & Rp. 920.277.684.000 & Rp. 789.722.590.616 \\
\hline 2018 & Rp. 979.737.828.000 & Rp. 993.680.640.931 \\
\hline
\end{tabular}

Sumber: KPP Pratama Subang, 2018

Berdasarkan tabel diatas, terlihat bahwa penerimaan dari sektor pajak untuk tingkat nasional setiap tahun nya mengalami peningkatan. Penerimaan pajak tahun 2014-2018 mengalami peningkatan yang tinggi dan tidak mengalami penurunan. Tetapi kenaikan atau realisasi penerimaan ini tidak sebanding dengan yang ditargetkan dan hanya tahun 2014 saja yang baru memenuhi target yang diharapkan. Jika melihat realisasi penerimaan pajak pada tahun 2014-2018 mengalami peningkatan tidak menutup kemungkinan realisasi penerimaan pajak pada tahun 2019 juga akan mengalami peningkatan.

Pemerintah melalui Direktorat Jendal Pajak terus berupaya dalam peningkatan penerimaan pajak. Salah satu upaya tersebut adalah dengan mengoptimalkan penerimaan pajak dari sektor Usaha, Mikro, Kecil, dan Menengah (UMKM).

Dalam pajak UMKM pemerintah semakin gencar dalam mengejar target penerimaan negara lebih dominan terlihat setelah merilis Peraturan Pemerintah yang mengatur perlakuan khusus Pajak Penghasilan untuk usaha mikro kecil dan menengah. Peraturan Pemerintah tersebut adalah Peraturan Pemerintah Nomor 46 Tahun 2013 pada awalnya tarif pajak $1 \%$ menjadi $0,5 \%$ terbit kemudian diluncurkan tanggal 22 Juni 2018 di Surabaya. Berdasarkan ketentuan ini, Wajib Pajak yang memenuhi kriteria dikenakan PPh Final. Terlebih Pemerintah saat ini sudah memangkas tarif pajak penghasilan (PPh) final bagi pelaku Usaha Mikro Kecil dan Menengah (UMKM) dari $1 \%$ menjadi $0,5 \%$. Kebijakan tersebut dimaksudkan untuk mendorong pelaku
UMKM agar lebih ikut berperan aktif dalam kegiatan ekonomi formal dengan memberikan kemudahan kepada pelaku UMKM dalam pembayaran pajak dan pengenaan pajak yang lebih berkeadilan, serta meningkatkan ketahanan ekonomi Indonesia. Selain itu, untuk mendorong peran masyarakat dalam kegiatan ekonomi formal, memberikan kemudahan dalam melaksanakan kewajiban perpajakan, lebih memberikan keadilan bagi UMKM, dan memberi kesempatan berkontribusi bagi negara (Pajak.go.id).

Terdapat beberapa faktor yang mempengaruhi wajib pajak tidak patuh dalam membayar pajak yaitu, kesadaran, moralitas, budaya pajak, dan keadilan distributif.

Kesadaran untuk membayar pajak tidak tumbuh di masyarakat, disebabkan adanya perbedaan kepentingan antara wajib pajak dengan pemerintah dalam pelaksanaan perpajakan. Sampai sekarang masih banyak masyarakat yang beranggapan bahwa pajak merupakan pungutan bersifat paksaan yang merupakan hak istimewa pemerintah dengan tidak memberikan kontraprestasi langsung kepada pembayar pajak (Nurfauzi, 2016).

Moralitas pajak tidak mengukur perilaku individu, namun lebih kepada sikap dan pendirian individu. Hal ini dapat dilihat sebagai kewajiban moral untuk membayar pajak, keyakinan untuk berkontribusi kepada masyarakat dengan membayar pajak (Khaerunnisa dan Wiratno, 2014).

Budaya pajak dalam konsep klasik dimana budaya pajak dari suatu negara sangat berhubungan erat dengan kepribadian yang ditunjukkan oleh evolusi dari suatu sistem perpajakan (llyas dan Burton, 2007) dalam (Khaerunnisa dan Wiratno, 2014).

Keadilan ini berhubungan dengan persepsi antar wajib pajak atas kesamaan hak dan kewajiban dalam pembayaran pajak. Semakin baik tingkat keadilan dalam sistem perpajakan yang dirasakan wajib pajak, maka semakin tinggi tingkat kepatuhan Wajib Pajak dalam membayar pajak (Yanti dkk, 2017). 
Sejauh ini sudah banyak penelitian mengenai fenomena kepatuhan wajib pajak dalam berbagai sudut pandang namun dalam penelitian ini penulis lebih berfokus pada sisi perilaku wajib pajak. Penelitian ini bertujuan untuk mengetahui pengaruh kesadaran, moralitas, budaya pajak dan keadilan distributif terhadap tingkat kepatuhan wajib pajak UMKM dalam membayar pajak.

Perbedaan dengan penelitian sebelumnya, penulis mengembangkan dari penelitian sebelumnya dan menambahkan variabel keadilan distributif pada penelitian (Ramadhan, 2017). Keadilan distributif ditambahkan karena penulis ingin mengetahui apakah wajib pajak merasa adanya keadilan yang diterima setelah membayar pajak atau tidak. Penelitian yang dilakukan Yanti, Yasa dan Dewi (2017) menunjukan bahwa moralitas wajib pajak berdasarkan hasil uji nilai berpengaruh signifikan terhadap kepatuhan pelaporan Wajib Pajak Orang Pribadi. Sedangkan hasil penelitian yang dilakukan Ramadhan (2017) menyatakan bahwa moralitas wajib pajak tidak berpengaruh positif dan signifikan terhadap kepatuhan Wajib Pajak UMKM.

Penelitian ini bertujuan untuk mengetahui pengaruh dari kesadaran, moralitas, budaya pajak, dan keadilan distributif terhadap kepatuhan wajib pajak.

\section{TINJAUAN PUSTAKA DAN PENGEMBANGAN HIPOTESIS}

\section{Teori Atribusi (Atribution Theory)}

Atribusi merupakan salah satu proses pembentukan persepsi maupun perilaku. Teori atribusi melihat seorang individu sebagai psikologi amatir yang mencoba memahami penyebab yang terjadi pada berbagai peristiwa atau kejadian yang dihadapinya. Teori atribusi juga mencoba menemukan apa yang menjadi penyebab seorang individu melakukan sebuah perilaku. Pada dasarnya, teori atribusi mengemukakan mengenai usaha ketika individu-individu mengamati perilaku untuk menentukan apakah perilaku tersebut ditimbulkan secara internal atau eksternal (Robbins dan Judge, 2008 dalam Yulianti, 2018).

Perilaku yang disebabkan secara internal adalah perilaku yang diyakini berada di bawah kendali pribadi individu itu sendiri, sedangkan perilaku yang disebabkan secara eksternal adalah perilaku yang dipengaruhi dari luar, artinya individu akan terpaksa berperilaku karena situasi.

Teori atribusi sangat relevan dengan penelitian ini karena kepatuhan wajib pajak terbentuk dari dalam diri wajib pajak masing-masing, tergantung pada bagaimana sikap wajib pajak dalam menilai pajak itu sendiri. Penilaian wajib pajak tentang pajak dapat dipengaruhi oleh faktor internal maupun eksternal.

Faktor tersebut juga terdapat pada penelitian ini sebagai variabel independen yang memungkinkan dapat mempengaruhi kepatuhan wajib pajak. Kesadaran dan moralitas seorang wajib pajak merupakan faktor internal dari diri wajib pajak yang dapat menentukan perilaku wajib pajak. Sedangkan budaya pajak dan keadilan distributif merupakan faktor eksternal yang dapat memungkinkan wajib pajak akan menilai sesuatu dan memutuskan untuk melakukan tindakan menurut apa yang mereka persepsikan.

\section{Pengembangan Hipotesis}

\section{Hubungan kesadaran terhadap kepatuhan wajib pajak \\ Menurut Suyatmin (2004) dalam} Ramadhan (2017) Kesadaran perpajakan adalah keadaan mengerti atau mengetahui perihal pajak. Dalam menggerakkan masyarakat agar mematuhi kewajiban membayar pajak, maka dibutuhkan penilaian positif terhadap pelaksanaan fungsi negara dari masyarakat.

Kesadaran sangat penting dalam pedoman pepajakan sehingga wajib pajak melaksanakan hak dan kewajiban perpajakannya. Karena bagaimana mungkin wajib pajak akan patuh jika mereka saja tidak sadar akan kewajiban perpajakannya. 
Jotopurnomo dan Mangoting (2013) mengatakan Kesadaran adalah keadaan mengetahui atau mengerti, sedangkan perpajakan adalah perihal pajak. Sehingga kesadaran perpajakan adalah keadaan mengetahui atau mengerti perihal pajak. Penilaian positif wajib pajak terhadap pelaksanaan fungsi negara oleh pemerintah akan menggerakkan masyarakat untuk mematuhi kewajibannya untuk membayar pajak. maka dari itu kesadaran Wajib Pajak mengenai perpajakan amatlah diperlukan guna meningkatkan kepatuhan Wajib Pajak.

Dalam penelitian Ramadhan (2017) yang menunjukan bahwa kesadaran memiliki hubungan dan berpengaruh signifikan terhadap kepatuhan wajib pajak.

Hal ini menunjukan bahwa semakin tinggi tingkat kesadaran wajib pajak semakin tinggi pula tingkat kepatuhan pajaknya. Oleh karena itu, hipotesis berikut dibuat untuk menentukan pengaruh kesadaran terhadap kepatuhan:

$\mathrm{H}_{1}$ : Kesadaran Pajak Berpengaruh positif terhadap Kepatuhan Pajak

\section{Hubungan moralitas terhadap kepatuhan wajib pajak}

Moralitas wajib pajak yang baik akan mendorong tingkat kepatuhan wajib pajak. Menurut Ramadhan (2017) Moralitas pajak merupakan sikap kepatuhan pajak yang ditunjukkan oleh kemauan wajib pajak untuk membayar pajak. Apabila kondisi moral masyarakat rendah, maka akan muncul motivasi untuk meloloskan diri dari kewajiban perpajakan dengan cara baik legal maupun ilegal.

Menurut Rahayu (2010) dalam Yasa, dkk (2017) bahwa moral masyarakat akan mempengaruhi pengumpulan pajak oleh fiskus. Dengan integritas tinggi tentunya pemenuhan kewajiban perpajakan akan lebih baik. Kepatuhan wajib pajak akan lebih baik jika moral penduduk baik. Keinginan untuk meloloskan diri dari pajak baik illegal maupun legal akan lebih termotivasi dengan kondisi moral masyarakat yang rendah.
Dalam penelitian Ramadhan (2017), Khaerunnisa dan Wiratno (2014) dan Yanti dkk, (2017) bahwa moralitas memiliki hubungan dan berpengaruh signifikan terhadap kepatuhan wajib pajak.

Hal ini menunjukan bahwa semakin tinggi tingkat moralitas wajib pajak semakin tinggi pula tingkat kepatuhan pajaknya. Oleh karena itu, hipotesis berikut dibuat untuk menentukan pengaruh moralitas terhadap kepatuhan:

$\begin{array}{ccc}\mathrm{H}_{2}: & \text { Moralitas } & \text { Berpengaruh } \\ \text { positifterhadap Kepatuhan Pajak }\end{array}$

\section{Hubungan budaya pajak terhadap minat kepatuhan wajib pajak}

Budaya pajak dalam konsep klasik dimana budaya pajak dari suatu negara sangat berhubungan erat dengan kepribadian yang ditunjukkan oleh evolusi dari suatu sistem perpajakan. Budaya pajak diinvestigasi diantara pembayar pajak dan kantor pajak. Dalam pandangan mereka, permasalahan yang terjadi antara "melakukan tuntunan atas kompensasi dalam hubungannya dengan pelanggaran pekerjaan oleh aparat pajak: dan "untuk memberikan kontribusi terhadap budaya pajak melalui perselisihan pajak" (Khaerunnisa dan Wiratno, 2017).

Widodo (2010) dalam Ramadhan (2017) mengatakan budaya pajak dibangun karena adanya interaksi baik formal maupun informal dalam suatu institusi yang menghubungkan sistem perpajakan nasional dengan praktk hubungan antara aparatur pajak.

Berdasarkan hal tersebut, hubungan antara aparatur pajak dengan wajib pajak merupakan salah satu indikator dari budaya pajak. Aparatur pajak diharapkan memiliki sifat jujur, simpatik, dan mudah untuk dihubungi karena aparatur pajak langsung berhubungan dengan wajib pajak dalam hal pelayanan perpajakan.

Dalam penelitian Ramadhan (2017) lalu Khaerunnisa dan Wiratno (2014) budaya pajak memiliki hubungan dan berpengaruh signifikan terhadap kepatuhan wajib pajak. 
Hal ini menunjukan bahwa semakin tinggi tingkat budaya pajak semakin tinggi pula tingkat kepatuhan pajaknya. Oleh karena itu, hipotesis berikut dibuat untuk menentukan pengaruh budaya pajak terhadap kepatuhan:

$\mathrm{H}_{3}$ : Budaya Pajak Berpengaruh positif terhadap Kepatuhan Pajak

\section{Hubungan keadilan distributif terhadap kepatuhan wajib pajak}

Keadilan distributif mengacu pada penilaian tentang keadilan hasil atau kebijakan Direktorat Jendral Pajak yang diterima oleh wajib pajak. Keadilan ini berhubungan dengan persepsi antar wajib pajak atas kesamaan hak dan kewajiban dalam pembayaran pajak. Semakin baik tingkat keadilan dalam sistem perpajakan yang dirasakan wajib pajak, maka semakin tinggi tingkat kepatuhan Wajib Pajak dalam membayar pajak (Yanti, Yasa dan Dewi, 2017).

Artawan, dkk (2017) mengatakan bahwa keadilan distributif secara konseptual juga berkaitan dengan distribusi keadaan atau barang yang akan berpengaruh terhadap kesejahteraan individu. Kesejahteraan individu yang dimaksudkan meliputi aspek-aspek fisik, psikologis, ekonomi, dan sosial.

Dari penelitian Yanti, dkk (2017) keadilan distributif memiliki hubungan dan berpengaruh signifikan terhadap kepatuhan wajib pajak.

Hal ini menunjukan bahwa semakin tinggi tingkat keadilan distributif semakin tinggi pula tingkat kepatuhan pajaknya. Oleh karena itu, hipotesis berikut dibuat untuk menentukan pengaruh moralitas terhadap kepatuhan:

$\mathrm{H}_{4}$ : Keadilan Distributif Berpengaruh positif terhadap Kepatuhan Pajak

5. Hubungan kesadaran, moralitas, budaya pajak dan keadilan distributif terhadap kepatuhan wajib pajak

Menurut hasil penilitian sebelum nya yang dilakukan oleh Ramadhan (2017) bahwa Kesadaran, Moralitas, dan Budaya
Pajak berpengaruh terhadap Kepatuhan Wajib Pajak. Sementara penelitian Yanti, Yasa, Dewi (2017) menyatakan bahwa Moralitas dan Keadilan Distributif juga berpengaruh terhadap Kepatuhan Wajib Pajak. Selanjutnya penelitian Khaerunnisa dan Wiratno (2014) Hasil pengujian hipotesis menunjukkan bahwa terdapat pengaruh moralitas pajak, budaya pajak, dan good governance terhadap kepatuhan wajib pajak.

Hal ini menunjukan bahwa semakin tinggi tingkat kesadaran, moralitas, budaya pajak, dan keadilan distributif semakin tinggi pula tingkat kepatuhan pajaknya. Oleh karena itu, hipotesis berikut dibuat untuk menentukan pengaruh moralitas terhadap kepatuhan.

$\mathrm{H}_{5}$ : Kesadaran, Moralitas, Budaya Pajak, dan Keadilan Distributif Berpengaruh positif terhadap Kepatuhan Pajak.

\section{METODOLOGI PENELITIAN}

\section{Metode Penelitian}

Penelitian ini menggunakan metode kuantitatif. Metode penelitian kuantitatif adalah metode penelitian kuantitatif. Sugiyono (2014) berpendapat bahwa, "Metode kuantitatif diartikan sebagai metode penelitian yang berlandaskan pada filsafat positiviste, digunakan untuk meneliti pada populasi atau sampel tertentu, pengumpulan data menggunakan instrument penelitian, analisis data bersifat kuantitatif/statistik, dengan tujuan untuk menguji hipotesis yang tetah di terapkan".

\section{Jenis dan Sumber Data}

Jenis data yang digunakan dalam penelitian ini adalah data kuantitatif. Data kuantitatif adalah data yang berbentuk angka atau data kualitatif yang diangkakan/scoring (Sugiyono, 2014). Sumber daya yang digunakan dalam penelitian ini adalah data primer. Data primer menurut (Sekaran dan Bougie, 2017) mengacu pada informasi yang diperoleh langsung (dari tangan pertama) oleh peneliti terkait dengan variabel ketertarikan untuk tujuan tertentu dari studi. Data didapatkan dengan 
membagikan kuesioner tertutup pada responden.

\section{Teknik Pengumpulan Data}

Teknik pengumpulan data merupakan langkah yang paling utama dalam penelitian, karena tujuan utama dari penelitian adalah mendapatkan data (Sugiyono, 2014). Dalam penelitian ini data yang digunakan yakni berdasarkan teknik kuesioner (angket) pada responden yaitu Wajib Pajak UMKM di Kabupaten Subang. Menurut (Sekaran dan Bougie, 2017) kuesioner adalah daftar pertanyaan tertulis yang telah dirumuskan sebelumnya di mana responden akan mencatat jawaban mereka, biasanya dalam alternatif yang didefinisikan dengan jelas. Sementara Sugiyono mengatakan bahwa "Kuesioner merupakan teknik pengumpulan data yang efisien bila peneliti tahu dengan pasti variabel yang akan diukur dan tahu apa yang bisa diharapkan dari responden (2014).

Kuesioner dalam penelitian ini disebarkan di Kabupaten Subang dengan wajib pajak UMKM sebagai responden. Data yang telah terkumpul kemudian diukur menggunakan skala pengukuran dan pemberian skor. Skor jawaban responden terdapat dalam tabel diabwah ini:

Tabel 3.1

Skor Jawaban Responden (skala likert)

\begin{tabular}{|c|l|c|}
\hline No & \multicolumn{1}{|c|}{ Jawaban Responden } & Skor \\
\hline 1 & Sangat Setuju (SS) & 5 \\
\hline 2 & Setuju (S) & 4 \\
\hline 3 & Netral (N) & 3 \\
\hline 4 & Tidak Setuju (TS) & 2 \\
\hline 5 & Sangat Tidak Setuju (STS) & 1 \\
\hline
\end{tabular}

Sumber: Data Primer yang diolah (2018)

\section{Populasi, Sampel, dan Teknik Pengambilan Sampel}

Menurut Sugiyono (2014) Populasi adalah wilayah generalis yang terdiri atas: obyek/subyek yang mempunyai kualitas dan karakteristik tertentu yang ditetapkan oleh peneliti untuk dipelajari dan kemudian ditarik kesimpulannya. Populasi dalam penelitian ini yaitu seluruh wajib pajak UMKM (Usaha Mikro, Kecil, dan Menengah) yang ada di Kota Subang.

Menurut Sugiyono (2014) sampel adalah bagian dari jumlah dan karakteristik yang dimiliki oleh populasi tersebut. Teknik pengambilan sampel yang digunakan dalam penelitian ini adalah sampling insidental yang termasuk kedalam nonprobability sampling. Sampling insidental adalah teknik penentuan sampel berdasarkan kebetulan, yaitu siapa saja yang secara kebetulan/insidental bertemu dengan peneliti dapat digunakan sebagai sampel, bila dipandang orang yang kebetulan ditemui itu cocok sebagai sumber data (Sugiyono, 2014). Jumlah sampel dari penelitian ini yaitu 107 wajib pajak UMKM yang ada di Kabupaten Subang. Jumlah sampel dalam penelitian ini di tentukan sesuai dengan pendapat Sekaran (2006) bahwa ukuran sampel yang dapat digunakan adalah $30-500$ sampel.

\section{Instrumen Penelitian}

Instrumen penelitian adalah suatu alat yang digunakan mengukur fenomena alam maupun sosial yang diamati. Secara spesifik semua fenomena ini disebut variabel penelitian (Sugiyono, 2014). Instrumen yang digunakan dalam penelitian ini adalah kuesioner yang mengukur kepatuhan wajib pajak, kesadaran, moralitas, budaya pajak dan keadilan distributif.
Tabel 3.3

Kisi-kisi Instrumen Penelitian Variabel Kesadaran Indikator No. Kuesione 


\begin{tabular}{|ll|c|}
\hline 1. & $\begin{array}{l}\text { Mengetahui adanya undang- } \\
\text { undang dan ketentuan } \\
\text { perpajakan. }\end{array}$ & 1,9 \\
2. $\begin{array}{l}\text { Mengetahui fungsi pajak untuk } \\
\text { pembiayaan negara. }\end{array}$ & $6,7,8,9$ \\
3. $\begin{array}{l}\text { Memahami fungsi pajak untuk } \\
\text { pembiayaan negara. }\end{array}$ & $2,3,4$ \\
4. $\begin{array}{l}\text { Menghitung, membayar, } \\
\text { melaporkan pajak dengan suka } \\
\text { rela. }\end{array}$ & 10 \\
5. $\begin{array}{l}\text { Menghitung, membayar, } \\
\text { melaporkan pajak dengan } \\
\text { benar. }\end{array}$ & 5 \\
6nggaraeni (2017) & 5 \\
\hline
\end{tabular}

Sumber : Peneliti (2018)

Tabel 3.4

Kisi-kisi Instrumen Penelitian Variabel Moralitas

\begin{tabular}{|c|c|c|}
\hline & Indikator & $\begin{array}{c}\text { No. } \\
\text { Kuesioner }\end{array}$ \\
\hline 1. & Partisipasi warga & $1,2,3,4,8$ \\
\hline 2. & $\begin{array}{l}\text { negara } \\
\text { Kepercayaan }\end{array}$ & 5 \\
\hline 3 . & Kebanggaan & 6,7 \\
\hline 4. & Sistem perpajakan & 9 \\
\hline \multicolumn{2}{|c|}{ Ramadhan (2017) } & \\
\hline
\end{tabular}

Sumber : Peneliti (2018)

Tabel 3.5

Kisi-kisi Instrumen Penelitian Variabel Budaya Pajak

\begin{tabular}{|l|c|}
\hline \multicolumn{1}{|c|}{ Indikator } & $\begin{array}{c}\text { No. } \\
\text { Kuesioner }\end{array}$ \\
\hline $1 . \quad \begin{array}{l}\text { Hubungan antara } \\
\text { aparatur pajak dengan } \\
\text { wajib pajak }\end{array}$ & $1,2,3,4,5$ \\
2. $\quad \begin{array}{l}\text { Peraturan Perpajakan } \\
\text { Ramadhan (2017) dan Alfiah } \\
\text { (2014) }\end{array}$ & 6,7 \\
\hline
\end{tabular}

Sumber : Peneliti (2018)
Tabel 3.6

Kisi-kisi Instrumen Penelitian Variabel Keadilan Distributif

\begin{tabular}{|l|l|}
\hline \multicolumn{1}{|c|}{ Indikator } & \multicolumn{1}{c|}{$\begin{array}{c}\text { No. } \\
\text { Kuesioner }\end{array}$} \\
\hline 1. & $\begin{array}{l}\text { Keadilan dalam } \\
\text { membayar pajak/ setiap } \\
\text { orang adi membayar } \\
\text { pajak. Dimana keadilan } \\
\text { ini merata atau yang } \\
\text { dianggap adil bagi semua } \\
\text { warga negara. }\end{array}$ \\
\hline \multicolumn{2}{|c|}{ Sumber : Peneliti (2018) }
\end{tabular}

Tabel 3.7

Kisi-kisi Instrumen Penelitian Variabel Kepatuhan Wajib Pajak

\begin{tabular}{|c|c|}
\hline \multicolumn{1}{|c|}{ Indikator } & $\begin{array}{c}\text { No. } \\
\text { Kuesioner }\end{array}$ \\
\hline 1. & $\begin{array}{l}\text { Kewajiban kepemilikan } \\
\text { NPWP }\end{array}$ \\
2. $\begin{array}{l}\text { Mengisi formulir pajak } \\
\text { dengan benar }\end{array}$ & $3,4,5$ \\
3. $\begin{array}{l}\text { Menghitung pajak dengan } \\
\text { jumlah yang benar }\end{array}$ & 6,7 \\
4. $\begin{array}{l}\text { Membayar pajak tepat } \\
\text { pada waktunya } \\
\text { Adiasa (2013) }\end{array}$ & 8 \\
\hline
\end{tabular}

\section{Skala Pengukuran}

Skala pengukuran merupakan kesepakatan yang digunakan sebagai acuan untuk menentukan panjang pendeknya interval yang ada dalam alat ukur, sehingga alat ukur tersebut bila digunakan dalam pengukuran akan menghasilkan data kuantitatif (Sugiyono, 2018). Skala yang digunakan dalam penelitian ini adalah skala likert. Skala Likert digunakan untuk mengembangkan instrumen yang digunakan untuk mengukur sikap, persepsi, dan pendapat seseorang atau sekelompok orang terhadap potensi dan permasalahan suatu objek, rancangan suatu produk, proses membuat produk dan produk yang telah dikembangkan atau diciptakan (Sugiyono, 2015). Skala likert yang digunakan yaitu alternatif model lima pilihan (skala lima).

Uji Kualitas Instrumen

1. Uji Validitas

Uji validitas digunakan untuk mengukur sah atau valid tidaknya suatu kuesioner . suatu kuesioner dikatakan valid jika pertanyaan pada kuesioner mampu untuk mengungkapkan sesuatu yang akan diukur oleh kuesioner tersebut (Ghozali, 2013). Pengujian validasi dilakukan dengan mengkorelasikan 
masing-masing item skor dengan total skor. Setelah $r$ hitung ditemukan, $r$ hitung tersebut kemudian dikonsultasikan dengan tabel untuk mengetahui butir yang valid dan tidak valid. Dengan pedoman bila $r$ hitung $\geq r$ tabel pada signifikansi $5 \%$ maka butir item dianggap valid,sedangkan bila $r$ hitung $<r$ tabel maka item itu dianggap tidak valid. Butir yang digunakan dalam pengumpulan data adalah butir yang valid (Ghozali, 2011) dalam (Yulianti, 2018).

\section{Uji Reliabilitas}

Instrumen yang reliabel adalah instrumen yang bila digunakan beberapa kali untuk mengukur obyek yang sama, akan menghasilkan data yang sama. Reliabilitas merupakan ukuran suatu kestabilan dan konsistensi responden dalam menjawab hal-hal yang berkaitan dengan konstrukkonstruk pertanyaan atau pernyataan yang merupakan dimensi suatu variabel dan disusun dalam suatu bentuk kuesioner (Khasanah, 2014) dalam (Yulianti, 2017). Suatu konstruk dikatakan reliabel jika memberikan nilai Cronbach Alpha $>0,60$ (Nunnaly, 1960 dalam Umiyati dan Nurmalasari, 2016).

\section{Teknik Analisis Data}

\section{Analisis Statistik Deskriptif}

Statistik deskriptif adalah statistik yang digunakan untuk menganalisa data dengan cara mendeskripsikan atau menggambarkan data yang telah terkumpul sebagaimana adanya tanpa bermaksud membuat kesimpulan yang berlaku untuk umum atau generalisasi. Termasuk dalam statistik deskriptif antara lain adalah penyajian data melalui tabel, grafik, diagram lingkaran, pictogram, perhitungan modus, median, mean (perhitungan tendensi sentral), perhitungan desil, persentil, perhitungan penyebaran data melalui perhitungan ratarata dan standar deviasi, perhitungan prosentase (Sugiyono, 2018).

\section{Analisis Kuantitatif}

Dalam analisis kuantitatif terdapat beberapa pengujian yaitu uji asumsi klasik, regresi berganda dan uji hipotesis yang akan dijelaskan seperti dibawah ini:

a. Uji asumsi klasik dalam penelitian ini menggunakan uji normalitas, uji linieritas, uji multikolinearitas dan uji heteroskedastisitas.

b. Teknik analisis berganda merupakan teknik uji yang digunakan untuk mengetahui pengaruh variabel indipende terhadap variabel dependen. Model yang digunakan dalam penelitian ini adalah:

$\mathrm{Y}=\mathrm{a}+\mathrm{b} 1 \mathrm{X} 1+\mathrm{b} 2 \mathrm{X} 2+\mathrm{b} 3 \mathrm{X} 3+$

b4X4 + e

Keterangan:

$\mathrm{Y}=$ Kepatuhan wajib pajak UMKM

a = Konstanta

b1-b4 = Koefisien regresi

$\mathrm{X} 1=$ Variabel Kesadaran

X2 = Variabel Moralitas

$\mathrm{X} 3=$ Variabel Budaya Pajak

X4 = Variabel Keadilan Distributif

$\mathrm{E}=$ Error

c. Uji Hipotesis terdapat tiga pengujian hipotesis dalam penelitian ini yaitu koefisien determinan $\left(R^{2}\right)$, uji simultan (Uji F), dan uji parsial (Uji t).

\section{HASIL DAN PEMBAHASAN}

\section{Hasil Uji Instrumen Penelitian Uji Validitas}

1. Kesadaran (X1)

Uji validitas untuk variabel kesadaran $\left(\mathrm{X}_{1}\right)$ terdiri dari 10 butir pernyataan. Hasil pengujian menunjukan bahwa semua pernyataan telah valid, karena nilai $r$ hitung lebih besar dari $r$ tabel, maka item-item tersebut dapat digunakan dalam model regresi. Berikut rincian hasil pengujian variabel $\mathrm{X}_{1}$ :
Tabel 4.9

Hasil Validitas Kesadaran Item-Total Statistics 


\begin{tabular}{|c|c|c|c|}
\hline & $\begin{array}{c}\text { Corrected Item- } \\
\text { Total } \\
\text { Correlation }\end{array}$ & r tabel & Hasil \\
\hline $\mathrm{X} 1.1$ & 0.461 & 0.1900 & Valid \\
\hline $\mathrm{X} 1.2$ & 0.658 & 0.1900 & Valid \\
\hline $\mathrm{X} 1.3$ & 0.670 & 0.1900 & Valid \\
\hline $\mathrm{X} 1.4$ & 0.581 & 0.1900 & Valid \\
\hline $\mathrm{X} 1.5$ & 0.597 & 0.1900 & Valid \\
\hline $\mathrm{X} 1.6$ & 0.639 & 0.1900 & Valid \\
\hline $\mathrm{X} 1.7$ & 0.631 & 0.1900 & Valid \\
\hline $\mathrm{X} 1.8$ & 0.541 & 0.1900 & Valid \\
\hline $\mathrm{X} 1.9$ & 0.679 & 0.1900 & Valid \\
\hline $\mathrm{X} 1.10$ & 0.618 & 0.1900 & Valid \\
\hline
\end{tabular}

Sumber : Hasil pengolahan data dengan SPSS versi 22

2. Mora;itas (X2)

Uji validitas untuk variabel moralitas $\left(\mathrm{X}_{2}\right)$ terdiri dari 9 butir pernyataan. Hasil pengujian menunjukan bahwa semua pernyataan telah valid, karena nilai $r$ hitung lebih besar dari $r$ tabel, maka item-item tersebut dapat digunakan dalam model regresi. Berikut rincian hasil pengujian variabel $\mathrm{X}_{2}$ :

Tabel 4.10

Hasil Validitas Moralitas Item-Total Statistics

\begin{tabular}{|c|c|c|c|}
\hline & $\begin{array}{c}\text { Corrected Item- } \\
\text { Total } \\
\text { Correlation }\end{array}$ & $\mathbf{r}$ tabel & Hasil \\
\hline $\mathrm{X} 2.1$ & 0.727 & 0.1900 & Valid \\
\hline $\mathrm{X} 2.2$ & 0.431 & 0.1900 & Valid \\
\hline $\mathrm{X} 2.3$ & 0.554 & 0.1900 & Valid \\
\hline $\mathrm{X} 2.4$ & 0.621 & 0.1900 & Valid \\
\hline $\mathrm{X} 2.5$ & 0.619 & 0.1900 & Valid \\
\hline $\mathrm{X} 2.6$ & 0.716 & 0.1900 & Valid \\
\hline $\mathrm{X} 2.7$ & 0.637 & 0.1900 & Valid \\
\hline X2.8 & 0.752 & 0.1900 & Valid \\
\hline X2.9 & 0.628 & 0.1900 & Valid \\
\hline
\end{tabular}

Sumber : Hasil pengolahan data dengan SPSS versi 22

\section{Budaya Pajak}

Uji validitas untuk variabel budaya pajak $\left(X_{3}\right)$ terdiri dari 8 butir pernyataan. Hasil pengujian menunjukan bahwa semua pernyataan telah valid, karena nilai $r_{\text {hitung }}$ lebih besar dari $r_{\text {tabel, }}$ maka item-item tersebut dapat digunakan dalam model regresi. Berikut rincian hasil pengujian variabel $\mathrm{X}_{3}$ :

\begin{tabular}{|c|c|c|c|}
\hline & $\begin{array}{c}\text { Corrected Item- } \\
\text { Total } \\
\text { Correlation }\end{array}$ & $\mathbf{r}$ tabel & Hasil \\
\hline X3.1 & 0.778 & 0.1900 & Valid \\
\hline X3.2 & 0.725 & 0.1900 & Valid \\
\hline X3.3 & 0.795 & 0.1900 & Valid \\
\hline X3.4 & 0.741 & 0.1900 & Valid \\
\hline X3.5 & 0.539 & 0.1900 & Valid \\
\hline X3.6 & 0.708 & 0.1900 & Valid \\
\hline X3.7 & 0.506 & 0.1900 & Valid \\
\hline X3.8 & 0.373 & 0.1900 & Valid \\
\hline
\end{tabular}

Sumber : Hasil pengolahan data dengan SPSS versi 22

\section{Keadilan Distributif}

Uji validitas untuk variabel keadilan distributif $\left(\mathrm{X}_{4}\right)$ terdiri dari 6 butir pernyataan. Hasil pengujian menunjukan bahwa semua pernyataan telah valid, karena nilai $r$ hitung lebih besar dari $r$ tabel, maka item-item tersebut dapat digunakan dalam model regresi. Berikut rincian hasil pengujian variabel $\mathrm{X}_{4}$ :

Tabel 4.12

Hasil Validitas Keadilan

Distributif Item-Total Statistics

\begin{tabular}{|c|c|c|c|}
\hline & $\begin{array}{c}\text { Corrected Item- } \\
\text { Total } \\
\text { Correlation }\end{array}$ & r tabel & Hasil \\
\hline X4.1 & 0.748 & 0.1900 & Valid \\
\hline X4.2 & 0.613 & 0.1900 & Valid \\
\hline X4.3 & 0.755 & 0.1900 & Valid \\
\hline X4.4 & 0.594 & 0.1900 & Valid \\
\hline X4.5 & 0.691 & 0.1900 & Valid \\
\hline X4.6 & 0.618 & 0.1900 & Valid \\
\hline
\end{tabular}

Sumber : Hasil pengolahan data dengan SPSS versi 22

\section{Kepatuhan (Y)}

Uji validitas untuk variabel minat menggunakan kepatuhan akuntansi (Y) terdiri dari 9 butir pernyataan. Hasil pengujian menunjukan bahwa semua pernyataan telah valid, karena nilai $r$ hitung lebih besar dari $r$ tabel, maka item-item tersebut dapat digunakan dalam model regresi. Berikut rincian hasil pengujian variabel $Y$ :
Tabel 4.11

Hasil Validitas Budaya Pajak Item-Total Statistics
Tabel 4.13

Hasil Validitas Kepatuhan Item-Total Statistics 


\begin{tabular}{|c|c|c|c|}
\hline & $\begin{array}{c}\text { Corrected Item- } \\
\text { Total } \\
\text { Correlation }\end{array}$ & r tabel & Hasil \\
\hline Y1 & 0.710 & 0.1900 & Valid \\
\hline Y2 & 0.811 & 0.1900 & Valid \\
\hline Y3 & 0.772 & 0.1900 & Valid \\
\hline Y4 & 0.827 & 0.1900 & Valid \\
\hline Y5 & 0.827 & 0.1900 & Valid \\
\hline Y6 & 0.695 & 0.1900 & Valid \\
\hline Y7 & 0.816 & 0.1900 & Valid \\
\hline Y8 & 0.696 & 0.1900 & Valid \\
\hline
\end{tabular}

Sumber : Hasil pengolahan data dengan SPSS versi 22

\section{Uji Reliabilitas}

Uji reliabilitas dilihat berdasarkan nilai Cronbach Alpha ( $\alpha$ ), dimana suatu variabel dikatakan reliabel apabila nilai Cronbach Alpha (a) > 0.60. Hasil pengujian menunjukan bahwa semua variabel telah dinyatakan reliabel, berikut adalah hasil uji reliabilitas dari masingmasing variabel:

Tabel 4.14

Hasil Uji Reliabilitas

\begin{tabular}{|c|c|c|}
\hline Variabel & $\begin{array}{c}\text { Cronbach's Alpha } \\
\text { Based on } \\
\text { Standardized } \\
\text { Items }\end{array}$ & Hasil \\
\hline Kesadaran & $\mathbf{0 . 8 8 1}$ & Reliabel \\
\hline Moralitas & $\mathbf{0 . 8 8 5}$ & Reliabel \\
\hline Budaya Pajak & $\mathbf{0 . 8 8 1}$ & Reliabel \\
\hline Keadilan Distributif & $\mathbf{0 . 8 7 0}$ & Reliabel \\
\hline Kepatuhan & $\mathbf{0 . 9 3 4}$ & Reliabel \\
\hline
\end{tabular}

Sumber : Hasil pengolahan data dengan SPSS versi 22

\section{Hasil Analisis Kuantitatif}

\section{Analisis Regresi Linier}

Di bawah ini merupakan tabel hasil regresi berganda yang bertujuan untuk membuktikan ada tidaknya pengaruh dari variabel Kesadaran $\left(X_{1}\right)$, Moralitas $\left(X_{2}\right)$, Budaya Pajak $\left(X_{3}\right)$, dan Keadilan Distributif $\left(\mathrm{X}_{4}\right)$ terhadap Tingkat Kepatuhan Wajib Pajak (Y):

Tabel 4.18

Hasil Analisis Regresi

$$
\text { Coefisien }^{\mathrm{a}}
$$

\begin{tabular}{|c|c|c|c|}
\hline \multirow{2}{*}{ Model } & $\begin{array}{c}\text { Unstandardized } \\
\text { Coefficients }\end{array}$ & $\mathbf{t}$ & Sig. \\
\cline { 2 - 4 } & $\mathbf{B}$ & & \\
\hline (Constant) & 0.313 & 1.145 & 0.255 \\
\hline X1 & 0.200 & 1.740 & 0.085 \\
\hline X2 & 0.462 & 3.609 & 0.000 \\
\hline X3 & 0.310 & 2.741 & 0.007 \\
\hline
\end{tabular}

\begin{tabular}{|c|c|c|c|}
\hline $\mathrm{X} 4$ & -0.048 & -.467 & 0.641 \\
\hline Sumber : Hasil pengolahan data dengan
\end{tabular} SPSS versi 22

Berdasarkan tabel diatas, hasil analisis regresi berganda menghasilkan koefisien untuk variabel bebas yaitu $X_{1}=$ $0.200 ; X_{2}=0.462 ; X_{3}=0.310 ;$ dan $X_{4}=-$ 0.048 dengan konstanta 0.313 . Dengan demikian, dapat dihasilkan persamaan regresi berganda sebagai berikut:

$$
\begin{gathered}
Y=0.313+0.200 X 1+0.462 X 2+0.310 \\
X 3-0.048 X 4+e
\end{gathered}
$$

Persamaan regresi berganda diatas memiliki makna sebagai berikut :

a. Konstanta (a) sebesar 0.313 mengartikan bahwa apabila kesadaran, moralitas, budaya pajak, dan keadilan distributif nilainya 0 , maka kepatuhan wajib pajak nilainya sebesar 0.313 .

b. Koefisien regresi kesadaran $\left(X_{1}\right)$ sebesar 0.200, mengartikan bahwa jika kesadaran mengalami peningkatan satu satuan, maka kepatuhan wajib pajak juga akan mengalami peningkatan sebesar 0.200 satuan.

c. Koefisien regresi moralitas $\left(X_{2}\right)$ sebesar 0.462, mengartikan bahwa jika moralitas mengalami peningkatan satu satuan, maka kepatuhan wajib pajak juga akan mengalami peningkatan sebesar 0.462 satuan.

d. Koefisien regresi budaya pajak $\left(X_{3}\right)$ sebesar 0.310, mengartikan bahwa jika budaya pajak mengalami peningkatan satu satuan, maka kepatuhan wajib pajak juga akan mengalami peningkatan sebesar 0.310 satuan .

e. Koefisien regresi keadilan distributif $\left(\mathrm{X}_{4}\right)$ sebesar -0.048 , mengartikan bahwa jika status keadilan distributif mengalami penurunan satu satuan, maka kepatuhan wajib pajak juga akan mengalami peningkatan sebesar 0.048 satuan.

\section{Hasil Uji Hipotesis Koefisien Determinan $\left(\mathbf{R}^{2}\right)$}


Koefisien determinan $\left(R^{2}\right)$ mencerminkan seberapa besar variabel independen mempengaruhi variabel dependen. Berdasarkan tabel hasil koefisien determinan $\left(\mathrm{R}^{2}\right)$ dibawah ini menunjukan bahwa nilai Adjusted $R$ Square adalah sebesar 0.617 yang menandakan bahwa variabel independen hanya $61 \%$ mempengaruhi variabel dependen, dan sisanya yaitu sebesar $39 \%$ pengaruh berasal dari faktor lain. Berikut adalah tabel hasil koefisien determinan $\left(R^{2}\right)$ :

Tabel 4.19

Hasil Koefisien Determinan $\left(\mathbf{R}^{2}\right)$

\begin{tabular}{|c|c|c|}
\hline $\mathbf{R}$ & R Square & Adjusted R Square \\
\hline $0.795^{\mathrm{a}}$ & 0.632 & 0.617 \\
\hline
\end{tabular}

Sumber : Hasil pengolahan data dengan SPSS versi 22

\section{Uji Simultan (Uji F)}

Pengujian ini bertujuan untuk mengetahui ada tidaknya pengaruh antara variabel independen $(X)$ dan variabel dependen (Y) secara simultan. Berdasarkan tabel 4.14 dibawah ini menunjukan bahwa nilai signifikan adalah sebesar 0.000 dimana nilai tersebut kurang dari $0.05 \quad(<0.05)$, hal tersebut menandakan bahwa varibel independen yang terdiri dari variabel kesadaran, moralitas, budaya pajak, dan keadilan distributif terhadap tingkat kepatuhan wajib pajak. Berikut adalah hasil uji simultan dari semua variabel independen terhadap variabel dependen :

\section{Tabel 4.20}

Hasil Uji Simultan (Uji F) ANOVA ${ }^{a}$

\begin{tabular}{|l|c|c|}
\hline & $\mathrm{F}$ & Sig. \\
\hline Regression & 43.763 & $.000^{\mathrm{b}}$ \\
\hline Residual & & \\
\hline Total & & \\
\hline
\end{tabular}

Sumber : Hasil pengolahan data dengan

SPSS versi 22

\section{Uji Parsial (Uji t)}

Pengujian ini bertujuan untuk mengetahui pengaruh dari variabel independen $(X)$ terhadap variabel dependen $(Y)$ secara parsial. Dibawah ini adalah hasil uji $t$ dari masing-masing variabel:

\section{Tabel 4.21}

Hasil Uji Parsial (Uji t)

\begin{tabular}{|c|c|c|c|}
\hline \multirow{2}{*}{ Model } & $\begin{array}{c}\text { Unstandardized } \\
\text { Coefficients }\end{array}$ & $\mathbf{t}$ & Sig. \\
\cline { 2 - 4 } & $\mathbf{B}$ & & \\
\hline (Constant) & 0.313 & 1.145 & 0.255 \\
\hline X1 & 0.200 & 1.740 & 0.085 \\
\hline X2 & 0.462 & 3.609 & 0.000 \\
\hline X3 & 0.310 & 2.741 & 0.007 \\
\hline X4 & -0.048 & -.467 & 0.641 \\
\hline
\end{tabular}

Sumber : Hasil pengolahan data dengan SPSS versi 22

Berdasarkan hasil uji parsial (uji t) pada masing-masing variabel, didapatkan hasil bahwa tiga dari lima variabel independen berpengaruh pada variabel dependen dengan batas minimum koefisien korelasi sig (p) 0.05 . Berikut adalah penjelasan hasil uji t dari setiap variabel :

1. Hipotesis pertama $(\mathrm{H} 1)$

Variabel kesadaran $\left(X_{1}\right)$ memiliki nilai signifikan sebesar 0.085 dimana nilai tersebut lebih dari $0.05 \quad(>0.05)$, ini menunjukan bahwa variabel kesadaran tidak berpengaruh terhadap tingkat kepatuhan wajib pajak. Dengan demikian hipotesis pertama $(\mathrm{H} 1)$ ditolak karena variabel kesadaran tidak berpengaruh terhadap tingkat kepatuhan wajib pajak.

\section{Hipotesis kedua $(\mathrm{H} 2)$}

Variabel moralitas $\left(\mathrm{X}_{2}\right)$ memiliki nilai signifikan sebesar 0.000 dimana nilai tersebut kurang dari $0.05 \quad(<0.05)$ dan bertanda positif (+), ini menunjukan bahwa variabel moralitas berpengaruh secara positif terhadap kepatuhan wajib pajak. Dengan demikian hipotesis kedua $(\mathrm{H} 2)$ diterima karena variabel moralitas berpengaruh secara positif terhadap kepatuhan wajib pajak.

3. Hipotesis ketiga $(\mathrm{H} 3)$

Variabel budaya pajak $\left(X_{3}\right)$ memiliki nilai signifikan sebesar 0.007 dimana nilai tersebut kurang dari $0.05 \quad(<0.05)$, dan bertanda positif (+), ini menunjukan bahwa variabel budaya pajak berpengaruh terhadap tingkat kepatuhan wajib pajak. Dengan demikian hipotesis ketiga $(\mathrm{H} 3)$ diterima karena variabel budaya pajak 
berpengaruh terhadap tingkat kepatuhan wajib pajak.

\section{Hipotesis keempat $(\mathrm{H} 4)$}

Variabel keadilan distributif $\left(\mathrm{X}_{4}\right)$ memiliki nilai signifikan sebesar 0.0641 dimana nilai tersebut lebih dari dari 0.05 $(>0.05)$, ini menunjukan bahwa variabel keadilan distributif tidak berpengaruh terhadap tingkat kepatuhan wajib pajak. Dengan demikian hipotesis keempat $(\mathrm{H} 4)$ ditolak karena variabel keadilan distributif tidak berpengaruh terhadap tingkat kepatuhan wajib pajak.

\section{Pembahasan}

\section{Pengaruh Kesadaran terhadap Tingkat Kepatuhan Wajib Pajak}

Berdasarkan hasil uji statistik yang telah dilakukan menunjukan bahwa tidak adanya pengaruh dari variabel kesadaran terhadap tingkat kepatuhan wajib pajak. Hal tersebut dapat dilihat dari hasil statistik uji regresi berganda yang ditunjukan dengan $X_{1}$ dimana nilai $t$ hitung sebesar 1740 dengan nilai signifikansi sebesar 0.085 , nilai tersebut lebih besar dari 0.05 (Sig. >0.05), maka hipotesis ketiga $(\mathrm{H} 1)$ dalam penelitian ini ditolak yang menyatakan bahwa kesadaran berpengaruh secara positif terhadap tingkat kepatuhan wajib pajak.

Hal tersebut tidak sesuai dengan teori atribusi dan penelitian dari Ramadhan (2017) yang menjelaskan bahwa kesadaram berpengaruh terhadap tingkat kepatuhan wajib pajak, karena mengacu pada teori atribusi mendefinisikan bahwa perilaku seseorang dapat ditimbulkan oleh faktor internal atau eksternal. Salah satu faktor internal yang dapat mempengaruhi seorang wajib pajak untuk patuh terhadap pajak adalah kesadaran pajak, karena faktor internal merupakan perilaku yang diyakini berada di bawah kendali pribadi itu sendiri misalnya faktor kepribadian, kesadaran dan kemampuan. Hal ini menunjukkan bahwa semakin tinggi kesadaran, maka kepatuhan wajib pajak akan semakin tinggi. Namun hasil penelitian ini bertentangan dengan teori dan penelitian terdahulu. Ini disebabkan oleh salah satu nya penghasilan pelaku UMKM yang rendah sehingga tidak memungkinkan mereka untuk membayar pajak, padahal mereka sadar akan kewajibannya.

Terdapat penelitian yang selaras dengan hasil penelitian ini yaitu penelitian dari Hidayati (2014) yang menyebutkan bahwa tidak ada pengaruh yang terjadi antara kesadaran terhadap tingkat kepatuhan wajib pajak.

\section{Pengaruh Moralitas terhadap Tingkat Kepatuhan Wajib Pajak}

Berdasarkan hasil uji statistik yang telah dilakukan menunjukan bahwa adanya pengaruh dari variabel moralitas terhadap tingkat kepatuhan wajib pajak. Hal tersebut dapat dilihat dari hasil statistik uji regresi berganda yang ditunjukan dengan $\mathrm{X}_{2}$ dimana nilai t hitung sebesar 3.609 dengan nilai signifikansi sebesar 0.000 , nilai tersebut lebih kecil dari 0.05 (Sig. <0.05) dan koefisien regresi memiliki tanda positif $(+)$, maka hipotesis kedua $(\mathrm{H} 2)$ dalam penelitian ini diterima yang menyatakan bahwa moralitas berpengaruh secara positif terhadap tingkat kepatuhan wajib pajak.

Adanya pengaruh antara moralitas terhadap tingkat kepatuhan menandakan bahwa adanya hubungan diantara faktor tersebut. Moralitas yang merupakan suatu motivasi yang dimiliki oleh individu atau dalam penelitian ini adalah pelaku UMKM terhadap kepatuhan dalam membayar kewajiban perpajakannya.

Hasil penelitian ini sesuai dengan teori atribusi yang mendefinisikan bahwa perilaku seseorang dapat ditimbulkan oleh faktor internal atau eksternal. Salah satu faktor internal yang dapat mempengaruhi seorang wajib pajak untuk patuh terhadap pajak adalah moralitas, karena faktor internal merupakan perilaku yang diyakini berada di bawah kendali pribadi itu sendiri. Selain itu hal tersebut dibahas dalam penelitian dalam penelitian Yanti, Yasa, dan Dewi (2017) menjelaskan bahwa moralitas berpengaruh positif signifikan terhadap kepatuhan. Hasil penelitian yang menyatakan bahwa moralitas pajak mempunyai hubungan searah dengan 
kepatuhan wajib pajak. Hal ini menunjukkan bahwa semakin tinggi moralitas pajak maka tingkat kepatuhan wajib pajak juga akan semakin tinggi. Sementara dalam penelitian Ramdhan (2017) yang menjelaskan bahwa moralitas tidak berpengaruh secara positif terhadap kepatuhan. Namun tidak selalu mempengaruhi perilakunya untuk patuh terhadap perpajakan, atau dapat dikatakan tidak akan menyebabkan tinggi atau rendahnya kepatuhan wajib pajak tersebut.

\section{Pengaruh Budaya Pajak terhadap Tingkat Kepatuhan Wajib Pajak}

Berdasarkan hasil uji statistik yang telah dilakukan menunjukan bahwa adanya pengaruh dari variabel budaya pajak terhadap tingkat kepatuhan wajib pajak. Hal tersebut dapat dilihat dari hasil statistik uji regresi berganda yang ditunjukan dengan $\mathrm{X}_{1}$ dimana nilai t hitung sebesar 2.741 dengan nilai signifikansi sebesar 0.007 , nilai tersebut lebih kecil dari 0.05 (Sig. <0.05) dan koefisien regresi memiliki tanda positif $(+)$, maka hipotesis kedua $(\mathrm{H} 3)$ dalam penelitian ini diterima yang menyatakan bahwa budaya pajak berpengaruh secara positif terhadap tingkat kepatuhan wajib pajak.

Hasil penelitian ini sesuai dengan teori atribusi yang mendefinisikan bahwa perilaku seseorang dapat ditimbulkan oleh faktor internal atau eksternal. Salah satu faktor eksternal yang dapat mempengaruhi seorang wajib pajak untuk patuh terhadap pajak adalah budaya pajak, karena faktor eksternal merupakan suatu hubungan antara wajib pajak dan aparatur pajak, jika hubungan tersebut tidak sejalan maka akan menimbulkan sikap acuh dari wajib pajak untuk memenuhi kewajiban perpajakannya.

Hasil penelitian ini sesuai dengan penelitian Ramdhan (2017) yang menjelaskan bahwa budaya pajak berpengaruh secara positif terhadap kepatuhan. Berdasarkan hasil penelitian, wajib pajak merasa bahwa realisasi hasil dari pajak tidak dapat langsung dinikmati, dan petugas pajak masih kurang mengerti akan kebutuhan wajib pajak. Berdasarkan hasil wawancara, wajib pajak masih kesulitan dalam hal penyusunan dan pelaporan perpajakan, dan bantuan dari petugas pajak juga masih kurang.

\section{Pengaruh Keadilan Distributif terhadap Tingkat Kepatuhan Wajib Pajak}

Berdasarkan hasil uji statistik yang telah dilakukan menunjukan bahwa tidak adanya pengaruh dari variabel keadilan distributif terhadap tingkat kepatuhan wajib pajak. Hal tersebut dapat dilihat dari hasil statistik uji regresi berganda yang ditunjukan dengan $\mathrm{X}_{4}$ dimana nilai t hitung sebesar -467 dengan nilai signifikansi sebesar 0.641, nilai tersebut lebih besar dari 0.05 (Sig. >0.05), maka hipotesis ketiga $(\mathrm{H} 3)$ dalam penelitian ini ditolak yang menyatakan bahwa keadilan distributif berpengaruh secara positif terhadap tingkat kepatuhan wajib pajak.

Hal tersebut tidak sesuai dengan

teori atribusi dan penelitian dari Ramadhan (2017) dan Artawan, Diatmika, dan Yasa (2017) yang menjelaskan bahwa keadilan distributif berpengaruh terhadap tingkat kepatuhan wajib pajak, karena keadilan distributif dapat mendorong Wajib Pajak untuk melaksanakan kewajiban perpajakannya. Jika keadilan distributif ini sudah dirasakan oleh Wajib Pajak maka akan dapat mendorong Wajib Pajak untuk melaksanakan kewajiban perpajakannya. Hal ini menunjukkan bahwa semakin tinggi keadilan distributif, maka kepatuhan wajib pajak akan semakin tinggi. Namun hasil penelitian ini bertentangan dengan teori dan penelitian terdahulu. Ini dikarenakan menurut responden atau para pelaku UMKM keadilan ini tidak membuat wajib pajak menjadi patuh dan peraturan pajak yang sangat mengikat dimana respoden memilih untuk bersikap patuh daripada rasa keadilan, lalu para responden merasa apa yang mereka bayarkan tidak sesuai dengan apa yang mereka dapatkan.

Menurut Mardiasmo (2009) dalam Yusmanda (2018), sesuai dengan tujuan hukum untuk mencapai keadilan, maka undang-undang dan pelaksanaan pemungutan harus adil. Adil dalam perundang-undangan yang dimaksud adalah mengenakan pajak secara umum 
dan merata, serta disesuaikan dengan kemampuan masing-masing. Sedangkan, adil dalam pelaksanaannya adalah memberikan hak kepada wajib pajak untuk mengajukan keberatan, penundaan dalam pembayaran dan mengajukan banding kepada Majelis Pertimbangan Pajak.

Terdapat penelitian yang selaras dengan hasil penelitian ini yaitu penelitian dari Kusuma (2016) yang menyebutkan bahwa tidak ada pengaruh yang terjadi antara keadilan distributif terhadap tingkat kepatuhan wajib pajak.

\section{Pengaruh Kesadaran, Moralitas, Budaya Pajak dan Keadilan Distributif terhadap Tingkat Kepatuhan Wajib Pajak}

Berdasarkan hasil uji $F$ yang dilakukan pada penelitian ini menunjukkan bahwa variabel kesadaran, moralitas, budaya pajak dan keadilan distributif mempunyai nilai Sig. sebesar 0,000 atau lebih kecil daripada 0,05. Hal ini menunjukkan bahwa variabel kesadaran, moralitas, budaya pajak dan keadilan distributif secara bersama-sama mempunyai kontribusi terhadap variabel kepatuhan wajib pajak. Jadi, dapat disimpulkan bahwa H5 diterima yaitu kesadaran, moralitas, budaya pajak dan keadilan distributif secara bersama-sama berpengaruh signifikan terhadap kepatuhan wajib pajak.

Berdasarkan nilai Adjusted $R$ Square $\left(R^{2}\right)$ sebesar 0.0617 yang menandakan bahwa pengaruh kelima variabel independen terhadap variabel dependen sebesar $61 \%$ dan sisanya yaitu sebesar $39 \%$ bisa jadi berasal dari faktor lain yang tidak diteliti pada penelitian ini. Dari hasil tersebut menunjukan bahwa hipotesis kelima $\left(\mathrm{H}_{5}\right)$ dalam penelitian ini diterima yang menyatakan variabel kesadaran, moralitas, budaya pajak dan keadilan distributif berpengaruh terhadap tingkat kepatuhan wajib pajak.

Semakin baik meningkatnya kesadaran, moralitas, budaya pajak dan keadilan distributif maka akan semakin meningkatkan penilaian yang baik terhadap tingkat kepatuhan wajib pajak.

\section{KESIMPULAN}

Berdasarkan hasil analisis data dan pembahasan dari masing-masing variabel yang telah dibahas di bab sebelumnya dalam penelitian ini, maka dapat disimpulkan bahwa:

1. Dari hasil penelitian ini diketahui bahwa semakin tinggi kesadaran tidak mempengaruhi tingkat kepatuhan wajib pajak, karena penghasilan pelaku UMKM yang kecil tidak memungkinkan mereka untuk membayar pajak meskipun mereka sudah sadar akan kewajibannya.

2. Dari hasil penelitian ini diketahui bahwa responden yaitu pelaku UMKM telah memiliki motivasi untuk melakukan kewajiban perpajakan nya, dan semakin tinggi moralitas mereka, maka semakin tinggi motivasi mereka terhadap tingkat kepatuhan mereka membayar pajak.

3. Dari hasil penelitian ini diketahui bahwa responden yaitu pelaku UMKM telah memiliki suatu hubungan yang baik dengan aparatur pajak untuk melakukan kewajiban perpajakan nya, dan semakin tinggi hubungan yang baik mereka, seperti kepercayaan mereka terhadap aparatur maka semakin tinggi pula mereka akan patuh dalam membayar pajak.

4. Dari hasil penelitian ini dikarenakan menurut responden atau para pelaku UMKM keadilan ini tidak membuat wajib pajak menjadi patuh dan peraturan pajak yang sangat mengikat dimana respoden memilih untuk bersikap patuh daripada rasa keadilan, lalu para responden merasa apa yang mereka bayarkan tidak sesuai dengan apa yang mereka dapatkan.

5. Dari hasil penelitian ini secara simultan kesadaran, moralitas, budaya pajak, dan keadilan distributif berpengaruh terhadap kepatuhan wajib pajak UMKM.

\section{KETERBATASAN}

Penelitian ini telah diusahakan untuk dilaksanakan dengan benar, namun 
demikian masih memiliki keterbatasan yaitu.

1. Penelitian ini hanya dilakukan di Kota Subang, sehingga masih kurang mewakili wajib pajak UMKM secara keseluruhan.

2. Kesibukan dari wajib pajak UMKM sehingga pengisian kuesioner kurang optimal.

3. Penelitian hanya menggunakan empat variabel yang mempengaruhi kepatuhan wajib pajak UMKM dan kemungkinan masih ada variabelvariabel lain yang dapat mempengaruhi kemauan membayar pajak.

4. Pernyataan dalam instrumen penelitian kurang komprehensif sehingga berpotensi untuk menimbulkan jawaban atau hasil yang bias.

\section{SARAN}

Berdasarkan kesimpulan dari hasil penelitian ini, ada beberapa saran untuk masukan kedepannya yaitu sebagai berikut:

1. Untuk penelitian selanjutnya dapat memperluas ruang lingkup tak hanya pelaku UMKM di Subang saja, agar responden yang didapat bisa lebih mencukupi, meskipun di kota Subang sudah banyak pelaku UMKM.

2. Untuk Pemerintah agar lebih meningkatkan sosialisasi agar dapat meningkatkan kepatuhan wajib pajak UMKM. Selain itu juga diharapkan dapat memberikan pengetahuan yang optimal dan lebih mengerti betapa penting nya membayar pajak meskipun apa yang sudah dibayarkan tidak secara langsung mereka dapatkan.

\section{DAFTAR PUSTAKA}

\section{Perundang-undangan}

Republik Indonesia. 2007. UndangUndang Nomor 28 Tahun 2007 Tentang Perubahan Ketiga atas Undang-Undang Nomor 6 Tahun 1983 tentang Ketentuan Umum dan Tata Cara Perpajakan
(Lembaran Negara Republik Indonesia Tahun 2007 Nomor 85, Tambahan Lembaran Negara Republik Indonesia Nomor 4740). Jakarta: Direktorat Jenderal Pajak Departemen Keuangan.

Peraturan Perundangan Meneteri Keuangan Nomor 46 Tahun 2013. Pajak Penghasilan Atas Penghasilan Dari Usaha Yang Diterima Atau Diperoleh Wajib Pajak Yang Memiliki Peredaran Bruto Tertentu.

Peraturan Perundangan Meneteri Keuangan Nomor 23 Tahun 2018. Pajak Penghasilan atas Penghasilan dari Usaha yang Diterima atau Diperoleh Wajib Pajak yang Memiliki Peredaran Bruto Tertentu

Undang-Undang Nomor 20 Tahun 2008. Usaha Mikro, Kecil dan Menengah (UMKM).

Peraturan Menteri Keuangan Republik Indonesia Nomor 192/PMK.03/2007 tentang Tata Cara Penetapan Wajib Pajak Dengan Kriteria Tertentu Dalam Rangka Pengembalian Pendahuluan Kelebihan Pembayaran Pajak.

\section{Sumber Buku}

Ghozali, Imam. (2013). Aplikasi Analisis Multivariete dengan Program IBM SPSS 23. Edisi VII. Badan Penerbit Universitas Diponogoro. Semarang.

Ghozali, Imam. (2016). Aplikasi Analisis Multivariete dengan Program IBM SPSS 21. Edisi VIII. Badan Penerbit Universitas Diponogoro. Semarang.

Sekaran, Uma dan Roger Bougie. 2017. Metode Penelitian untuk Bisnis. Edisi 6. Penerbit Salemba Empat. Jakarta.

Sugiyono. 2014. Metode Penelitian Kombinasi (Mixed methods). Penerbit Alfabeta Bandung. 
Sugiyono. (2018). Metode Penelitian Bisnis. Penerbit Alpabeta. Bandung

Sugiyono. 2015. Metode Penelitian \& Pengembangan (Research and Development). Penerbit Alfabeta CV. Bandung.

Umiyati, Indah \& Nunik Nurmalasari. (2016). Statistik Penelitian Pengenalan Aplikasi SPSS dan Eviews. Penerbit STIESA Press. Subang

Sumber Skripsi dan Jurnal

Adiasa. 2013. Pengaruh Pemahaman Peraturan Pajak Terhadap Kepatuhan Wajib Pajak Dengan Preferensi Risiko Sebagai Variabel Moderating.

Aismawanto, 2018. Faktor-Faktor Yang Mempengaruhi Kepatuhan Wajib Pajak Dalam Membayar Pajak Wajib Pajak Umkm ( Studi Empiris Umkm Yang Ada Di Kota Bandar Lampung ). SKRIPSI. Universitas Lampung.

Anggraeni, 2017. Pengaruh Kesadaran Wajib Pajak, Lingkungan Wajib Pajak, Sikap Religiusitas Wajib Pajak, Dan Kemanfaatan Npwp Terhadap Kepatuhan Wajib Pajak (Studi Empiris Pada Wajib Pajak Orang Pribadi Yang Terdaftar Di Kantor Pelayanan Pajak Pratama Klaten.Universitas Muhammadiyah Yogyakarta.

Artawan, Diatmika Dan Yasa. 2017. Pengaruh Pemeriksaan Pajak Dan Keadilan Distributif Terhadap Kepatuhan Wajib Pajak Orang Pribadi Non Karyawan (Studi Empiris Pada Kantor Pelayanan Pajak Pratama Singaraja. eJournal S1 Ak Universitas Pendidikan Ganesha Jurusan Akuntansi Program S1 (Vol: 8 No: 2 Tahun 2017).

Budhiarsana, 2016. Kepuasan Sebagai Pemoderasi Pengaruh Keadilan Distributif, Penegakan Sanksi Pada Kepatuhan Wajib Pajak Hotel Dan Restoran. ISSN : 2337-3067 E-Jurnal Ekonomi dan Bisnis
Universitas Udayana 5.4 (2016) : 721-748

Dewi, 2018. Pengaruh Kualitas Layanan, Pengetahuan Perpajakan, Sanksi Pajak, Dan Tingkat Perkembangan Moral Terhadap Kepatuhan Wajib Pajak Orang Pribadi. SKRIPSI. Universitas Islam Indonesia.

Hidayah, 2014. Analisis Faktor-Faktor Yang Mempengaruhi Kepatuhan Wajib Pajak Dalam Membayar Pajak Bumi Dan Bangunan (Pbb) Di Kota Yogyakarta Tahun 2013. SKRIPSI. Universitas Negeri Yogyakarta.

Hidayati, 2014. Analisis Pengaruh Kesadaran Wajib Pajak, Pengetahuan Dan Pemahaman Tentang Peraturan Perpajakan, Efektifitas Sistem Perpajakan, Pelayanan Fiskus, Dan Sanksi Pajak Terhadap Kepatuhan Wajib Pajak Orang Pribadi (Studi Kasus Pada Kpp Pratama Surakarta).Jurnal. Universitas Muhammadiyah Surakarta.

Jotopurnomo dan Mangoting, 2013. Pengaruh Kesadaran Wajib Pajak, Kualitas Pelayanan Fiskus, Sanksi Perpajakan, Lingkungan Wajib Pajak Berada terhadap Kepatuhan Wajib Pajak Orang Pribadi di Surabaya. TAX \& ACCOUNTING REVIEW, VOL.1, NO.1, 201.

Khaerunnisa dan Wiratno, 2014. Pengaruh Moralitas Pajak, Budaya Pajak, Dan Good Governance Terhadap Kepatuhan Wajib Pajak. Jurnal Riset Akuntansi dan Perpajakan, JRAP Vol. 1 no. 2, hal 211-224 ISSN 2339 - 1545.

Kundalini, 2016. Pengaruh Kesadaran Wajib Pajak Dan Pelayanan Pegawai Pajak Terhadap Kepatuhan Wajib Pajak Pada Kantor Pelayanan Pajak Pratama Kabupaten Temanggung Tahun 2015. SKRIPSI. Universitas Negeri Yogyakarta.

Kusuma, 2016. Pengaruh Penegakan Sanksi, Keadilan Distributif Dan Kepuasan Pada Kepatuhan Wajib Pajak Di Kpp Mataram Barat. 
SKRIPSI. Universitas Udayana Denpasar.

Lukman dan Fajriana, 2016. Pengaruh Sikap Fiskus, Lingkungan Wajib Pajak, Keadilan Pajak Dan Sistem Administrasi Perpajakan Terhadap Kepatuhan Wajib Pajak Orang Pribadi Dalam Membayar Pajak (Studi Empiris Pada Wajib Pajak Orang Pribadi Yang Terdaftar Di Kpp Pratama llir Barat I Palembang).Jurnal. STIE Multi Data Palembang.

Nugraheni, 2015. Faktor-Faktor Yang Mempengaruhi Kepatuhan Wajib Pajak Orang Pribadi (Studi Empiris Pada Wajib Pajak Di Kota Magelang). SKRIPSI. Universitas Diponegoro Semarang.

Nugraheni dan Purwanto, 2015. FaktorFaktor Yang Mempengaruhi Kepatuhan Wajib Pajak Orang Pribadi (Studi Empiris Pada Wajib Pajak Di Kota Magelang). Volume 4, Nomor 3, Tahun 2015, Halaman 1-14 ISSN (Online): 2337-3806. Universitas Diponegoro Semarang.

Nugroho, 2016. Faktor-Faktor Yang Mempengaruhi Kemauan Membayar Pajak Wajib Pajak Orang Pribadi Yang Melakukan Pekerjaan Bebas Di KPP Pratama Yogyakarta. SKRIPSI. Universitas Negeri Yogyakarta.

Nurfauzi, 2016. Faktor-Faktor Yang Mempengaruhi Kepatuhan Wajib Pajak Dalam Membayar Pajak Bumi Dan Bangunan Perdesaan Dan Perkotaan Di Kecamatan Wanasari Kabupaten Brebes.

Purnaditya dan Rohman, 2015. Pengaruh Pemahaman Pajak, Kualitas Pelayanan Dan Sanksi Pajak Terhadap Kepatuhan Pajak (Studi Empiris Pada Wp Op Yang Melakukan Kegiatan Usaha Di Kpp Pratama Semarang Candisari. Volume 4, Nomor 4, Tahun 2015, Halaman 1-11 ISSN (Online): 2337-380. Universitas Diponegoro Semarang.

Ramadhan. 2017. Pengaruh Kesadaran, Moralitas Dan Budaya Pajak
Terhadap Kepatuhan Pajak (Studi Pada Ukm Siola Kota Surabaya).

Riswandi, 2014. Faktor-Faktor Yang Berpengaruh Terhadap Kepatuhan Wajib Pajak Umkm Yang Terdaftar Di Kpp Pratama Makassar Utara. SKRIPSI. Universitas Islam Negeri Alauddin Makassar.

Safri, 2013. Pengaruh Kesadaran Wajib Pajak Terhadap Kepatuhan Wajib Pajak Orang Pribadi Yang Melakukan Pekerjaan Bebas (Studi Di Wilayah Kpp Pratama Yogyakarta). SKRIPSI. Universitas Negeri Yogyakarta.

Sani dan Habibie, 2017. Pengaruh Moral Wajib Pajak, Sikap Wajib Pajak dan Norma Subjektif terhadap Kepatuhan Pajak melalui Pemahaman Akuntansi. Jurnal Ilman, Vol. 5, No. 2, pp. 80-96, September 2017, ISSN 2355-1488. STIE Harapan Medan.

Sari, 2014. Pengaruh Kesadaran Wajib Pajak Dan Sanksi Perpajakan Terhadap Kepatuhan Wajib Pajak (Studi Empiris pada Dinas Pendapatan dan Pengelolaan Keuangan Daerah) Kabupaten Bandung.

Syaiful, 2016. Pengaruh Kesadaran Wajib Pajak, Administrasi Perpajakan, Dan Sanksi Pajak Terhadap Kepatuhan Wajib Pajak Pajak Bumi Dan Bangunan (Studi Empiris Di Kecamatan Koto Tangah Padang). ARTIKEL. Universitas Negeri Padang.

Tatik, 2018. Potensi Kepatuhan Pembayaran Pajak Pada Pelaku Umkm (Usaha Mikro Kecil Dan Menengah) Pasca Penerbitan Peraturan Pemerintah Nomor 23 Tahun 2018 (Studi Kasus Pada Umkm Di Kabupaten SlemanYogyakarta). Seminar Nasional dan Call for Paper Sustainable Competitive Advantage (SCA) 8 Purwokerto, 19 September 2018. Universitas Islam Indonesia.

Yanti, Yasa Dan Dewi. 2017. Pengaruh Sikap Wajib Pajak, Moralitas Pajak Dan Keadilan Distributif Terhadap Tingkat Kepatuhan Wajib Pajak 
Orang Pribadi Dalam Membayar Pajak Pada Kantor Pelayanan Pajak Pratama Gianyar. e-Journal S1 Ak Universitas Pendidikan Ganesha Jurusan Akuntansi Program S1 (Vol:8 No:2 Tahun 2017).

Yusmanda, 2018. Pengaruh Persepsi Keadilan Pajak Dan Detection Rate Terhadap Penggelapan Pajak. ARTIKEL. Universitas Negeri Padang.

Yulianti, 2018. Pengaruh Pengetahuan Perpajakan Dan Persepsi Keadilan Terhadap Tingkat Kepatuhan Wajib Pajak Melalui Kepercayaan (Studi Kasus Pada Wajib Pajak PP 46 Tahun 2013 yang Terdaftar di KPP Pratama Subang). SKRIPSI. Sekolah Tinggi Ilmu Ekonomi Sutaatdmadja Subang.

Yusro dan Kiswanto, 2014. Pengaruh Tarif Pajak, Mekanisme Pembayaran Pajak Dan Kesadaran Membayar Pajak Terhadap Kepatuhan Wajib Pajak UMKM Kabupaten Jepara. AAJ 3 (4) (2014) Accounting Analysis Journal. Jurusan Akuntansi, Fakultas Ekonomi, Universitas Negeri Semarang, Indonesia.

\section{Situs Website}

www.pajak.go.id/setengahpersen www.wikipedia.org https://kbbi.kemdikbud.go.id https://www.konsistensi.com/2013/07/ujimultikonieritas-denganmelihat.html (Diakses pada tanggal 19 Mei 2019) http://duwiconsultant.blogspot.com/2011/ 11/uji-multikolinearitas.html (Diakses pada tanggal 19 Mei 2019)

https://www.spssindonesia.com/2014/02/u ji-multikolonieritas-denganmelihat.html (Diakses pada tanggal 19 Mei 2019)

https://www.statistikian.com/2016/11/ujimultikolinearitas.html (Diakses pada tanggal 19 Mei 2019)

https://tonyteaching.wordpress.com/2010/ 11/15/memperbaiki-normalitasdengan-transformation-data/ (Diakses pada tanggal 16 Mei 2019)

http://duwiconsultant.blogspot.com/2011/11/u ji-normalitas.html (Diakses pada tanggal 16 Mei 2019)

https://www.advernesia.com/blog/spss/carauji-normalitas-spss-shapiro-wilk-dankolmogorov-smirnov/ (Diakses pada tanggal 16 Mei 2019)

https://www.statistikian.com/2013/02/ujinormalitas-pada-spss.html (Diakses pada tanggal 16 Mei 2019) 